Nama : Gamos Cristo S

NIM : 312020165

\title{
TUGAS ANALISIS JURNAL
}

A. IDENTITAS JURNAL

1. Nama Jurnal : Jurnal teologi injil dan pembinaan warga jemaat

2. Volume : 3

3. Nomor : 1

4. Halaman : $100-112$

5. Tahun Penerbit : 2019

6. Judul Jurnal : Gereja dan kemiskinan

7. Nama Penulis : Fibry Jati Nugroho

B. ISI JURNAL

Permasalahan kemiskinan bukan hanya menjadi masalah lokal,namun menjadi masalah yang digumulkan oleh dunia, greja merupakan mandataris Tuhan ditengah permaslahan kemiskinan yang ada di dunia, dalam jurnal ini kita akan mengetahui lebih mendalam tentang peran gereja dalam mengatasi kemiskinan yang ada di dunia,yaitu dimana gereja sebagai institusi/lembaga memiliki peran yang sangat strategis sekaligus tanggung jawab yang besar, peran strategis tersebut adalah menjadi motivator, dinamisator, fasilitator, dan organisator, serta gereja perlu berperan aktif memberikan solusi bagi pergumulan masyarakat,tidak hanya melakukan aksi social,yang tampak membantu sesaat,tetapi perlu usaha trnsformatif agar dapat memberikan jawaban yang tepat dalam usaha membantu masyarakat,kemiskinan merupakan pergumulan masyarakat yang selalu menjadi pemikiran strategis nasional untuk diselesaikan ,senada dengan hal ini, tugas dan panggilan gereja adalah menyuarakan ketidakadilan dan keberpihakan gereja kepada kaum yang tertindas, dalam pengentasan masalah sosial terutama kemiskinan grejajuga memiliki peran untuk menyuarakan kritik profetisnya tanpa pandang bulu terhadap praktik penyalahgunaan kekuasaan, yang mengakibatkan ketidakadilan dan membuat sistem yang memiskinkan masyarakat, dalam jurnal ini juga memberitahukan kepada kita betapa pentingnya peningkatan spiritual yang harus dilakukan geraja terhadap jemaat,sehingga jemaat mempunyai kesalehan social dan kepedulian social di tengah masyarakat,sehingga jemaat juga mampu merefleksikan spiritualitas di lingkungan masyarakat sekitarnya,sehingga masyarakat dapat merasakan Tuhan hadir pula di tengah pergumulannya

\section{KELEBIHAN DAN KEKURANGAN}

1. Kelebihan

Kelebihan dari jurnal ini adalah pembahasan mengenai konsep dan peran gereja dalam mengatasi kemiskinan dibahas cukup baik,cukup relevant dengan keaadaan yang sedang terjadi dan begitu berguna untuk menjadi acuan penyelesaian masalah kemiskinan.

\section{Kekurangan}

Menurut saya jurnal ini sudah cukup baik. 